Dokuz Eylül Üniversitesi-Mühendislik Fakültesi

Fen ve Mühendislik Dergisi

Cilt 20, Sayı 59, Mayıs, 2018
Dokuz Eylul University-Faculty of Engineering Journal of Science and Engineering Volume 20, Issue 59, May, 2018

DOI: $10.21205 /$ deufmd. 2018205925

\title{
Surface Potential Correlations with Irregular Plastic Deformation
}

\author{
Ahmet YILMAZ*1 \\ 1Yalova University, Engineering Faculty, Chemical and Process Engineering \\ Department, 77100, Yalova.
}

(Alınıș / Received: 04.11.2016, Kabul / Accepted: 14.02.2018, Online Yayınlanma / Published Online: 15.05.2018)

Keywords

Surface Potential, Electrochemistry, TensileTesting, Serrated plastic deformation, Dislocations

\begin{abstract}
Surface potential of aluminum alloy AA 3204 undergoing an irregular (serrated) plastic flow was monitored in $0.1 \mathrm{M} \mathrm{NaCl}$ solution under various strain rates from $1.0 \times 10^{-4} / \mathrm{s}$ to $2.0 \times 10^{-5} / \mathrm{s}$ at RT $\left(20^{\circ} \mathrm{C}\right)$. Large potential bursts at the stress drop periods of the irregular flow were revealed. Number and frequency of the stress drops along the plastic region matched with that of the bursts precisely, and average burst magnitude was found to be related with that of the stress drops. The observations affirmed an in-situ utility of the electrochemical method for monitoring deformation and damage evolution in aqueous environments for materials susceptible to irregular flow.
\end{abstract}

\section{Yüzey Potansiyelinin Düzensiz Plastik Deformasyon ile Korelasyonu}

Anahtar Kelimeler Yüzey potansiyeli, Elektrokimya,

Cekme testi, Düzensiz plastik deformasyon, Dislokasyonlar
Özet: Düzensiz (kesikli) plastik deformasyona uğrayan AA 3204 aluminyum alașımının yüzey potansiyeli oda sıcaklı̆̆ındaki $\left(20^{\circ} \mathrm{C}\right)$ $0.1 \mathrm{M} \mathrm{NaCl}$ çözeltisi içinde, $1.0 \times 10^{-4} / \mathrm{s}$ ve $2.0 \times 10^{-5} / \mathrm{s}$ arasında değişen çeşitli germe hıları altında izlendi. Düzensiz deformasyondaki stres düşüşleri sırasında büyük potansiyel taşmaları ortaya çıktı. Plastik bölge boyunca stres düşüş sayısı ve sıklığı potansiyel taşmalarınınki ile tam olarak uyuştu. Gözlemler elektrokimyasal yöntemin düzensiz deformasyona yatkın malzemelerin sulu ortamlardaki deformasyon ve zararının izlenmesinde kullanışlı olduğunu ortaya koydu. 


\section{Introduction}

Most material qualities deteriorate through the irregular plastic deformation which is also called as the Portevin LeChatelier (PLC) Effect. This localized type of a deformation appearing in small sections (bands) of load bearing dilute alloys brings out crucial structural issues. Aluminum alloys and steel are susceptible to the effect under moderate strain rates even at/around room temperatures. The effect induces loss in ductility along with losses in percent elongation, time to failure, effective cross section area, and fracture toughness. Due to the embrittlement created by the effect unprecedented failures become feasible for the susceptible load bearing alloys [1,2].

Employment of the susceptible materials in aqueous environments can cause further environmental problems that may end up with catastrophic failures. For instance, stress corrosion and hydrogen embrittlement of alloys in aqueous media can swiftly increase degradation rates on those locally deforming bands. Also, localized corrosion processes such as pitting and crevicing can readily be available for the susceptible materials having thin passive layers [3]. Such local deformation in a form of band can easily rupture the passive layers and expose fresh metal sites with extra residual strains for localized type of a corrosion to initiate and proceed.

The exact microscopic nature of the effect still remains undefined. However, number of investigation techniques have been used successfully in detection of macroscopic and spatio-temporal features of the local deformation bands $[4,5]$. The bands come out in different types such as type $A$, type $B$, etc. and move along the effective gauge in various manners, sometimes by splitting in

different directions. Commonly used techniques such as optical imaging,

thermographic imaging, acoustic emission, magnetic flux measurement, electric field measurement, and laser scanning extensometry have helped display almost all macroscopic features of the bands [6-8]. In general, higher strain rates require higher temperatures, and wise verse, for occurence of the deformation bands and the subsequent irregular plastic flow with repetitive stress drops.

As most studies were devoted to investigation of macroscopic features of the bands, there are only a few studies on correlations of the stress drops of the effect with other physical phenomena occuring on the test specimens. A study using an electrochemical method was reported some impedance changes during a serrated flow of an alloy [9], where the effect was more appearent with thinner passive films of the alloy. Another study using electric field measuremens showed some charge fluctuations during the local deformation [10].

This work presents a swiftly emerging potential shift in a proportional manner with the stress drop of the local banding events during the irregular plastic flow of the studied alloy. This is a newly observed phenomenon that shows a charge build-up on the surface of the alloy experiencing an irregular plastic flow. Details of the observed potential shifts and utility of the set-up for investigation of the effect have been discussed.

\section{Materials and Methods}

Tensile test specimens of cold drawn AA 3204 (1.0 wt $\% \mathrm{Mn}+1.0$ wt $\% \mathrm{Mg}$ ) with 
gauge dimensions of $27.0 \mathrm{~mm}$ X $6.0 \mathrm{~mm}$ X $0.17 \mathrm{~mm}$ were wet polished with 1200 grit emery paper, and rinsed with distilled water before installing into a $250 \mathrm{~mL}$ glass made cell filled with freshly prepared 0.1 moles/L aqueous $\mathrm{NaCl}$ solution (pH: 6.0, dissolved oxygen: 7.1 $\mathrm{mg} / \mathrm{L})$. Then the cell was mounted onto a Zwick/Roell made screw-driven universal test machine by gripping the exposed specimen roots in the machines jaws. Figure 1 shows the electrochemical cell and arrangement of the cell elements used. Then, scanning of surface potential (open circuit potential) of the alloy was started. A Parstat 4 model potentiostat with software (Princeton Research Co.) was used for monitoring the surface potential of the specimens strained under various rates from $1.0 \times 10^{-4} / \mathrm{s}$ to $2.0 \times 10^{-5} / \mathrm{s}$. The reference electrode (SCE; $\mathrm{Hg} / \mathrm{Hg}_{2} \mathrm{Cl}_{2}$ ) tip was held in a fixed distance of $10.0 \mathrm{~mm}$ from the specimen surfaces at a mid-level of the effective gauge in the cell. Surface potential of the alloy became fairly stable at $-0.75 \mathrm{~V}$ about 1 hour after starting the scanning. Then, the tensile tests with predetermined strain rates were started. Tensile test data were acquired and analyzed by TestExpert software embedded to the test machine. All tests carried out at the ambient lab temperature of $20{ }^{\circ} \mathrm{C}$ with deviations about $0.5^{\circ} \mathrm{C}$ from the mean.

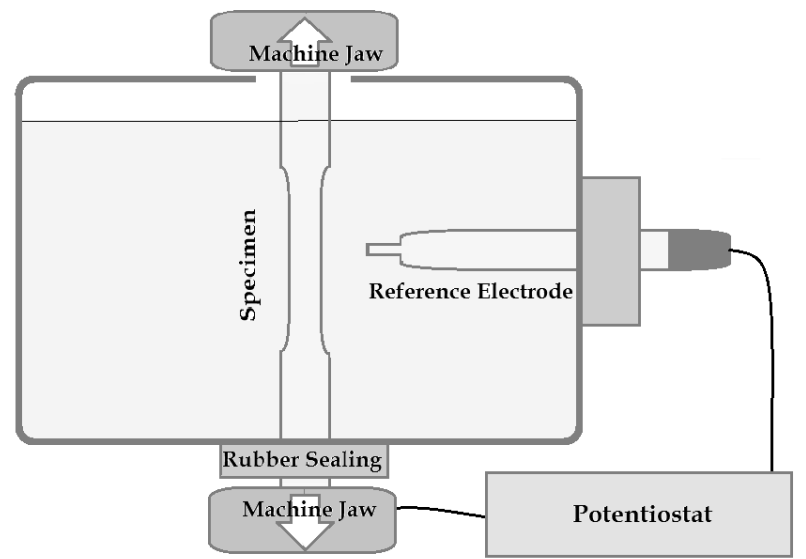

Figure 1. A Schematic of the test cell and arrangement of the cell elements

\section{Results}

In the elastic regime of the tensile tests the surface potential did not show any significant deviation from the stabilized value of $-0.750 \mathrm{mV}$. When approaching to the yield point, the surface potential readings became more fluctuated but staying under a $0.5 \mathrm{mV}$ range at most. The level of the fluctuations were considerably small to create any significant affect on the observations of surface potential behavior during the stress drops of the plastic flow.
Figure 2 shows a characteristic pair of stress-elongation and potential-time curve in the plastic region obtained under a rate of $4.0 \times 10^{-5} / \mathrm{s}$. The surface potential (open circuit potential) screening combined with tensile testing of the alloy in the plastic deformation regime revealed precisely coupling potential bursts with stress drops of the PLC effect under strain rates between $1.0 \times 10^{-4} / \mathrm{s}$ and $2.0 \times 10^{-5} / \mathrm{s}$ at $20{ }^{\circ} \mathrm{C}$. As the bursts closely resembled the serrations the count and frequency of both events were found to be the same. Starting moments of stress drops and 
accompanying bursts were observed to be close. Also, saturation and ending times for both events were observed to be close under potential measurement periods selected between $0.2 \mathrm{~s}$ to $1.0 \mathrm{~s}$. Magnitudes of stress drops and potential bursts, in their average values, were found to be proportional with each other in all pairs of the stress-potential data acquired. Stress drop magnitudes, especially of lower strain rates, were fairly stable while the burst magnitudes appeared to be spreading about $15 \%$ of their mean value in general.

The irregular flow starting after the yield proceeded on through the entire plastic region in the strain rate range used. Average magnitudes of the both events showed an increasing trend with decreasing strain rates, and average magnitudes of the bursts were found to be increasing with increasing average stress drops as given in Figure 3. The average values were calculated by

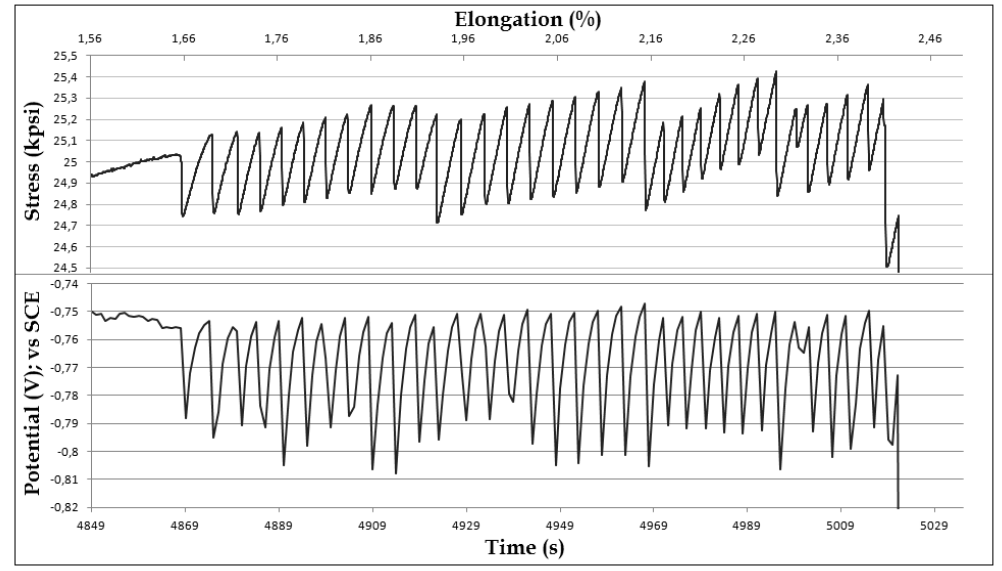

Figure 2. Precisely correlated events ( stress drops and potential bursts) of AA 3204 strained under a rate of $4.0 \times 10^{-5} / \mathrm{s}$ at $20^{\circ} \mathrm{C}$.

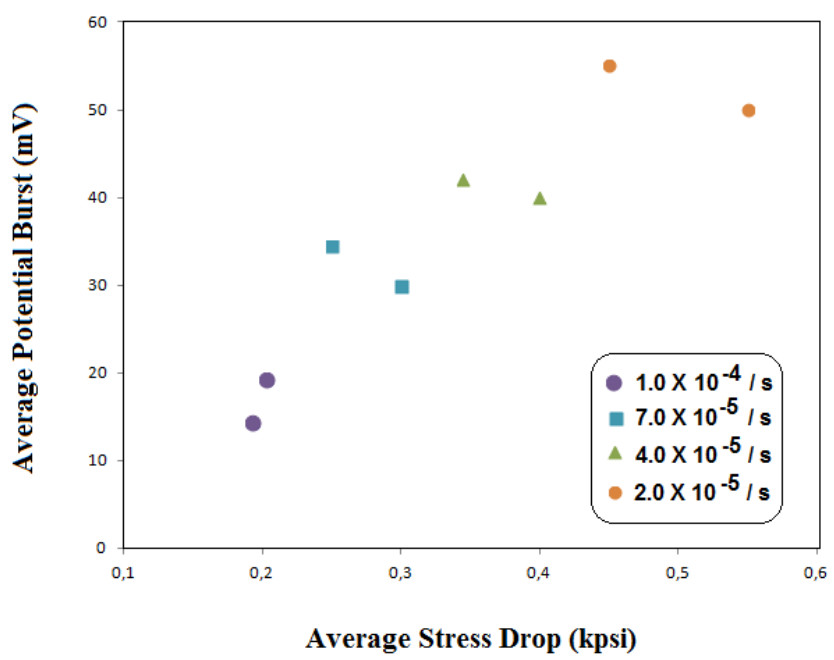

Figure 3. Trend of the average magnitudes of the observed events for AA 3204 strained from $1.0 \times 10^{-4} / \mathrm{s}$ to $2.0 \times 10^{-5} / \mathrm{s}$ at $20^{\circ} \mathrm{C}$. 
summing single event magnitudes and dividing it by the total number of the events, while the extreme stress drops and corresponding bursts were not taken into account. The trend observed between the average magnitudes appeared to fit onto a common curve of a linear or a quadratic form as can be seen in Figure 3.

\section{Discussion}

The potential bursts correlating precisely with the stress drops of the unstable flow given in Figure 2 closely represent the general appearance of the tests carried out under strain rates from $1.0 \times 10^{-4} / \mathrm{s}$ to $2.0 \times 10^{-5} / \mathrm{s}$. The close resemblance in emerging time and magnitude of the bursts and the drops, suggests an existence of a connection in between the two events. The observed potential burst magnitudes are rather large which gets about as much as $55 \mathrm{mV}$ under the slowest strain rate employed $\left(2 \times 10^{-5} / \mathrm{s}\right)$, and they occur swiftly.

Any potential shift of that amount in a rapid manner may not be originating from a change in the reaction controls of the local action cells, namely anodic and cathodic regions in the effective gauge of the specimen. The ongoing reactions at the passive film-solution and metalpassive film interfaces during such a slow straining can change only gradually [11]. In other words, no significant change was present on any of the test parameters (such as temperature, strain rate, dissolved oxygen concentration, etc.) to cause the large potential shift observed.

Besides, with no rupture in the passive film, no fresh alloy surface can be exposed to the test solution. And, there can be no sensing of any extra potential upon the red-ox changes at the metalsolution interface, and/or possible other sources such as residual stresses left over on the alloys surface. An intact passive layer on the alloy with its fair electrical resistance would have a concealing effect for those extra potential sources on the metal. Therefore, a film rupturing effect of some agents and a large potential source on the fresh surface of the alloy are foremost needed for observation of such a phenomenon.

Rupturing of the passive layer is quite a plausible during each stress drop of the irregular flow experienced by the alloy. Unlike a regular plastic flow, an irregular flow is localized in a narrow band (PLC band) in the effective gauge of the specimen. Thus, the plastic deformation would be rigorously high in magnitude in that constrained section of the effective gauge. A rapid avalanche like plastic flow [12] during a stress drop would exert a force on to the overlaying passive film in normal and many other directions, that would shatter the passive layer easily.

The extent of the rupture depends mainly on thickness and brittleness of the passive layer. The layer on the studied alloy can be safely estimated to be around 3-5 nm, considering some work in the literature that are relevant with the present case. For instance, thickness of the air formed passive layer on pure Al specimens measured by XPS was reported to be in between 3.7 and $4.8 \mathrm{~nm}$ by several independent authors $[13,14]$. Passive layer thickness of anodically polarized pure $\mathrm{Al}$ specimens at RT in deaerated $0.1 \mathrm{M} \mathrm{NaCl}$ were measured to be about $4.9 \mathrm{~nm}$ by $\mathrm{x}$-Ray photoelectron spectroscopy (XPS) below pitting potential. The thickness was measured to be $3.8 \mathrm{~nm}$ when polarization voltage was set to $-0.750 \mathrm{~V}$ vs SCE, and a further decrease in potential caused little or no change in the thickness [15]. Since the passivation behavior of alloy AA 3204 is in a close proximity to that of the pure alloy [16] of above, the passive layer should easily be ruptured by a deforming large local band. 
The deformation bands of the actual specimens were visible to naked eye and their width was estimated to be in a range of $1 / 4 \mathrm{~mm}$. And, this band width is a measure of the amount of collapse in the band during the deformation. A depiction of a local band with its emerging slip steps rupturing passive layer is given in Figure 4.

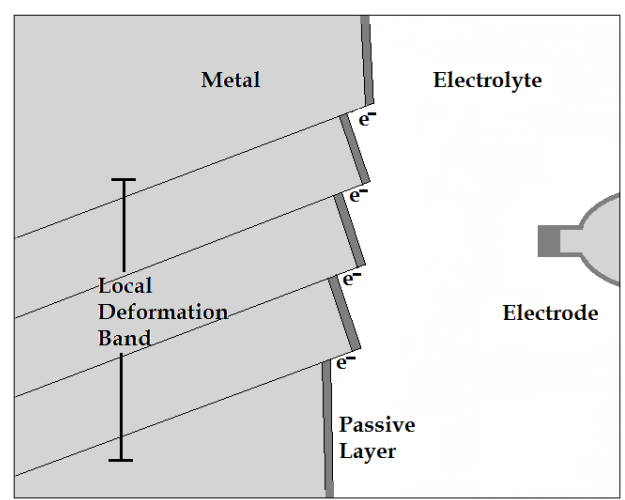

Figure 4. A depiction of a localized deformation band exposing electrons by slip step emerging into electrolyte.

Thus, the large local deformation bands look capable of rupturing the thin passive layers, most likely at each time they emerge. Because, the band width is incomparably larger than the thickness of the passive layer. However, one still has to explain the source of the rapid and rather large (50-60 $\mathrm{mV}$ under the lowest strain rates) potential bursts observed with each stress drop in the entire range of the irregular flow.

Early studies $[17,18]$ showed that straining of metals and alloys was reducing their electrical conductivity (via increasing the electrical resistance). The effect was explained as a reduction of the free electron density via binding of some amount of electrons in the vicinity of dislocations by the straining effect (also known as the cold work effect). These are the bound states where the electrons are not active in electrical or thermal conduction.
During a local deformation of a band, the deformation slip steps rapidly emerging with an avalanche like manner would be exposed to the electrolyte by rupturing the passive layer, as illustrated in Fig 4. Then the exposed top and bottom facets of the slip steps carrying dislocation core domains would expose the electrons that are bound with stress fields of dislocations created with the cold work effect (by the straining). Thus, each slip step may carry certain amount of a charge which is likely proportional with the total exposure area. This rapidly appearing charge of a certain amount at the interface then can be detected as a potential burst, as carried out in the present work.

The proportional change in magnitudes of the both events depicted in Figure 3 may be attributed to a relationship between cumulative slip step surface area and exposed charge amount. Since dislocation density of the slip planes for each developping band at different sections of the gauge may not vary much, the number of electrons per a load drop should depend on the surface area of the related localized band.

The presented testing method proves to be useful for screening especially the irregular deformation progress and consequent damage on mission specific alloys used in aqueous media. Besides, a lab-scale use for investigating irregular flow of alloys look promising, since number of electrons exposed to the test solution during the load drops of the flow is measurable. Furthermore, when the counted electrons by the method is combined with dislocation event counts of acoustic emission method [6], a typical length of a dislocation segment involved in the effect can be calculated. The method is relatively simple, and easy to set-up, and does not require any amplification/filtering, or any embedded extra device. 


\section{Conclusions}

The surface potential magnitudes precisely correlating with the stress drops of the irregular flow is a newly observed effect in an electrochemical setup. The observations are significant because of a useful utility of the method

\section{References}

[1] Robinson, J.M. 1994. Int. Mater. Rev., Vol.39, p.113.

[2] Yilmaz, A. 2011. Sci. Technol. Adv. Mater., Vol.12, , p.063001

[3] Jones, D.A. 1996. Principles and prevention of corrosion, Second Edition, Prentice Hall Inc., Upper Saddle River, NJ.

[4] Ananthakrishna, G. 2007. Phys. Rep., Vol.440, p.113.

[5] McCormick, P.G. 1986. Trans. Indian Inst. Met., Vol.39, p.98.

[6] Chmelik, F. Klose, F.B, Dierke, H. Sachl, J. Neuhauser, H. and Lukac, P. 2007. Mat. Sci. Eng. A, Vol.462, p.53.

[7] Ait-Amokhtar, H. Fressengeas, C. and Boudrahem, S. 2008. Mat. Sci. Eng. A, Vol.488, p.540.

[8] Zdunek, J. Brynk, T. Mizera, J. Pakiela, Z. and Kurzydlowski, K. 2008. J. Mater. Charact., Vol.59, p.1429.

[9] Darowicki, K. Orlikowski, J. 2007. Electrochim. Acta, Vol.52, p.4043.

[10] Schmitter, E.D. 2007. Phys. Lett. A, Vol.368, p.320. in aqueous solutions for monitoring ongoing irregular deformations of mission critical alloys. Besides, the tests can be used to estimate number of electrons contributing to a localized band formation, which may be useful in modeling studies of the effect.

[11] Roberts, K.J. Shemilt, L.W. 1969 Trans. Inst. Chem. Eng., Vol.47, p.204.

[12] Ananthakrishna, G. 2007. Dislo cations in Solids, ed: Nabarro, F.R.N. and Hirth, J.P. Elsevier Publishing, New York USA.

[13] Strohmeier, B.R. 1990. Surf. Interface Anal., Vol.15, p.51.

[14] Yu, S.Y. O'Grady, W.E. Ramaker, D. E. and Natishan, P.M. 2000. J. Electrochem. Soc.,Vol.147, P.2952.

[15] Chang, C. L. Sankaranarayanan, K. R.S. Engelhard M.H. Shutthanandan, V. Ramanathan, S. 2009. J. Phys. Chem. C, Vol.113, P.3502.

[16] Polmear, I.J. 2006. Light alloys : from traditional alloys to nanocrystals,Elsevier, Butterworth -Heinemann, Burlington, MA.

[17] Landauer, R. 1951. Phys. Rev. vol. 82, p.520.

[18] Koehler, J.S. 1949. Phys. Rev. vol.75, p.106. 